Andrews, J. \& Brook, M. (r968). Geront. clin. 2, 28.

Andrews, J., Brook, M. \& Allen, M. A. (I966). Geront. clin. 8, 257.

Andrews, J., Fairley, A. \& Barker, R. (1967). Scott. med. \%. 12, 208.

Anonymous (1967). Br.med.7. ii, 652 .

Boscott, R. J. \& Cooke, W. T. (1954). Q. $f l$ Med. 23, 307.

British Medical Association (1950). Report of the Committee on Nutrition. London: British Medical Association.

Cooper, B. A. \& Lowenstein, L. (I g66). Br. F. Haemat. 12, 283.

Crandon, J. H. (1940). New Engl. F. Med. 223, I0.

Exton-Smith, A. N. \& Stanton, B. R. (1965). Report of an Investigation into the Dietary of Elderly Women Living Alone. King Edward's Hospital Fund for London.

Girdwood, R. H., Thomson, A. D. \& Williamson, J. (1967). Br. med. F. ii, 670.

Griffiths, L. L., Brocklehurst, J. C., Scott, D. L., Marks, J. \& Blackley, J. (1967). Geront. clin. 9, 1. Herbert, V. (1962). Trans. Ass. Am. Physns 75, 307.

Hoffbrand, A. V., Newcombe, B. F. A. \& Mollin, D. L. (1966). F. clin. Path. r9, 17.

Hurdle, A. D. F. (1967). MD Thesis, Lniversity of London.

Kataria, M. S., Rao, D. B. \& Curtis, R. C. (1965). Geront. clin. 7, I89.

Lowenstein, L., Cantlie, G., Ramos, O. \& Brunton, L. (rg66). Can. med. Ass. F. 95, 797.

Tattersall, R. N. \& Seville, R. (1950). Q. fl Med. I9, I5I.

Taylor, G. (I 966). Lancet i, 926 .

Will, G. \& Groden, B. (1965). Scott. med. F. ro, 2 r.

Williams, R. J. \& Deason, G. (1967). Proc. natn. Acad. Sci U.S.A. 57, 6.

\title{
Mineral metabolism in relation to ageing
}

By D. A. Smith and I. Harrison, University Department of Medicine, Gardiner Institute, Western Infirmary, Glasgow, $W \mathrm{I}$, B. E. C. Nordin, MRC Mineral Metabolism Research Unit, Leeds General Infirmary, Leeds, and J. MACGREGor and M. JoRDan, Strathclyde University, George Street, Glasgow

Osteoporosis is a common condition, occurring more frequently in women than in men. It is especially common in women after the onset of the menopause. Beck \& Nordin ( 1960 ) reported osteoporosis in $12 \%$ of males and $23 \%$ of females dying in the Western Infirmary, Glasgow. Collins (1959) in a similar study reported an incidence of $8 \%$ in men and $18 \%$ in women over the age of 40 dying in the General Infirmary, Leeds.

Albright, Burnett, Cope \& Parsons (194I) and Albright, Smith \& Richardson (1941) from a study of osteoporosis in post-menopausal women, and women with Cushing's syndrome, suggested that the primary defect in osteoporosis was a failure in the synthesis of bone matrix. Nordin (1958, I960) suggested that osteoporosis in man might result from prolonged negative calcium balance.

It has been shown (Light \& Frey, I 94I; Greaves, Scott \& Scott, I959; Harrison $\&$ Fraser, I960) that a variety of laboratory animals fed on a low-calcium diet, but with adequate vitamin $\mathrm{D}$ and phosphorus, developed osteoporosis. Jowsey \& Gershon-Cohen (1964) confirmed these findings in cats. They also demonstrated that cats made osteoporotic with a low-calcium diet, and then given supplementary calcium, showed an increase in bone density. That a positive calcium balance can be produced in osteoporotic patients by feeding supplementary calcium has been reported by a number of authors (Owen, Irving \& Lyall, I940; Anderson, 1950; 
Whedon, I959; Harrison \& Fraser, I961; Nordin, I962). The relation between the calcium intake and osteoporosis in man is therefore of considerable interest. Smith \& Frame ( 1965 ) investigated 2000 ambulatory women. They found a progressive loss in vertebral density and of cortical bone in the metacarpal and femur with age. They were not, however, able to demonstrate any relation between osteoporosis and calcium intake obtained from a dietary history.

In this paper, we report the dietary intake of calcium, phosphorus, protein and vitamin $D$ in normal female subjects and patients referred to a special clinic because they were thought to have osteoporosis. Calcium absorption was estimated by an isotope test of absorption, and the urinary calcium estimated in the same subjects.

\section{Subjects studied}

Two groups of subjects were studied. The first consisted of $5^{2}$ normal female volunteers, approached while they were visiting patients in the wards of the Western Infirmary, Glasgow (Nordin, MacGregor \& Smith, 1966). Diet histories are available in $14 \mathrm{I}$ of these subjects. The second was a group of ninety-seven patients referred for the investigation and treatment of severe back pain or recent fractures, and who were thought to have osteoporosis by the referring physician or surgeon on examination of standard bone X-rays.

\section{Procedure.}

The subjects were interviewed and a standard questionnaire was completed by a member of the medical staff. The questionnaire was designed to include a history of backache, fracture, bowel symptoms, urinary tract and endocrine disorders. Details of the menstrual and obstetric history were also noted. All of the subjects had their height and weight taken. Skeletal X-rays and bone densitometry measurements were carried out as described by Nordin et al. ( 1966 ), and an oral test of radioactive calcium absorption was performed (Bhandarkar, Bluhm, MacGregor \& Nordin, 196r). Random urine specimens were taken on two separate occasions and the mcan of the two calcium:creatinine ratios was recorded. Patients with secondary osteoporosis (Nordin, r96r) were excluded from the survey.

Diet histories, with particular reference to calcium, phosphorus, protein and vitamin $\mathrm{D}$, were obtained from all the subjects by a dietitian specifically employed for this purpose. The validity of the diet histories in terms of the weighed weekly diet is being reported elsewhere (Harrison \& Nordin). All the findings were recorded and processed by a medical data processing system utilizing magnetic tape record files and flexible search and statistical routines.

\section{Results}

The social class of the I 52 normal female volunteers, according to their husbands' occupations (or their own if single or widowed) was described in our previous paper (Nordin et al. 1966), and is reproduced in Table 1 . This classification is in accordance with Appendix Br of the Registrar General's Classification of Occupations ( 1960 ). 
There was a preponderance of patients in class 3 (skilled occupations). The social class distribution of the patients described as osteoporotic is shown in Table $\mathbf{r}$ and is very similar to that of the normal subjects.

The average age of the onset of the menopause was 47 years in the normal group and 46.6 years in the patient group, the subjects who had had an artificial menopause being excluded. There was no significant difference between the groups. A higher proportion of the supposedly osteoporotic group had had artificial menopauses $(23 \%)$ as compared with the normal group (10\%).

\section{Table I. Social classes of the subjects}

\begin{tabular}{|c|c|c|c|c|}
\hline \multirow[b]{2}{*}{ Class } & \multicolumn{2}{|c|}{ Notmals } & \multicolumn{2}{|c|}{ Osteoporotics } \\
\hline & No. & $\%$ & No.* & $\%$ \\
\hline I Professional, etc. & 6 & 43 & 3 & 3 \\
\hline 2 Senior executive & I4 & $9 \cdot 8$ & 9 & 10.0 \\
\hline 3 Skilled & 96 & $68 \cdot 1$ & 57 & $63 \cdot 3$ \\
\hline 4 Semi-skilled & 18 & $12 \cdot 8$ & 14 & 15.6 \\
\hline 5 Unskilled & 7 & $5 \cdot 0$ & 7 & $7 \cdot 8$ \\
\hline
\end{tabular}

*The social class was not recorded in seven of the ninety-seven patients thought to be osteoporotic.

The X-ray indices were correlated with age (Table 2). It is clear that, except for the spine index in the osteoporotic group, the $\mathrm{X}$-ray indices of bone mass fall significantly with age in both groups. The two groups were, therefore, compared by relating the metacarpal index, the femoral index, the spine score and the relative vertebral density (RVD) to age, in 5-year age groups. The results of the comparison relating the metacarpal index to age are shown in Fig. $\mathrm{r}$. As can be seen, there was no significant difference between the two groups. Similarly, when the two groups were compared in terms of the femoral index, spine index and relative vertebral index, no significant difference emerged.

Table 2. Correlation analysis of $X$-ray indices $(y)$ on age $(x)$

$\begin{array}{cccc}\text { Subjects } & \text { X-ray index } & \begin{array}{c}\text { Correlation } \\ \text { coefficient (r) }\end{array} & P \\ \text { Normals } & \text { Femoral } & -0.40 & <0.00 \mathrm{I} \\ & \text { Spine } & -0.26 & <0.005 \\ \text { Hand } & -0.64 & <0.00 \mathrm{I} \\ \text { RVD } & -0.50 & <0.00 \mathrm{I} \\ \text { 'Osteoporotics' } & \text { Femoral } & -0.36 & <0.00 \mathrm{I} \\ & \text { Spine } & \mathrm{NS} & <0.00 \mathrm{I} \\ & \text { Hand } & -0.59 & <0.00 \mathrm{I} \\ \text { Normals and } & \text { RVD } & -0.40 & <0.00 \mathrm{I} \\ \text { Festeoporotics' } & \text { Femoral } & -0.46 & <0.00 \mathrm{I} \\ & \text { Hane } & -0.30 & <0.00 \mathrm{I} \\ & \text { RVDd } & -0.67 & <0.00 \mathrm{I} \\ & \text { RVD } & -0.55 & \text { NS, not significant. }\end{array}$

The mean and two standard error range of intake of calcium ( $\mathrm{mg} /$ day), phosphorus (mg/day), protein (g/day), and vitamin D (i.u./day) in the normal and osteoporotic groups are shown in Fig. 2. There was a significantly lower intake of phosphorus 


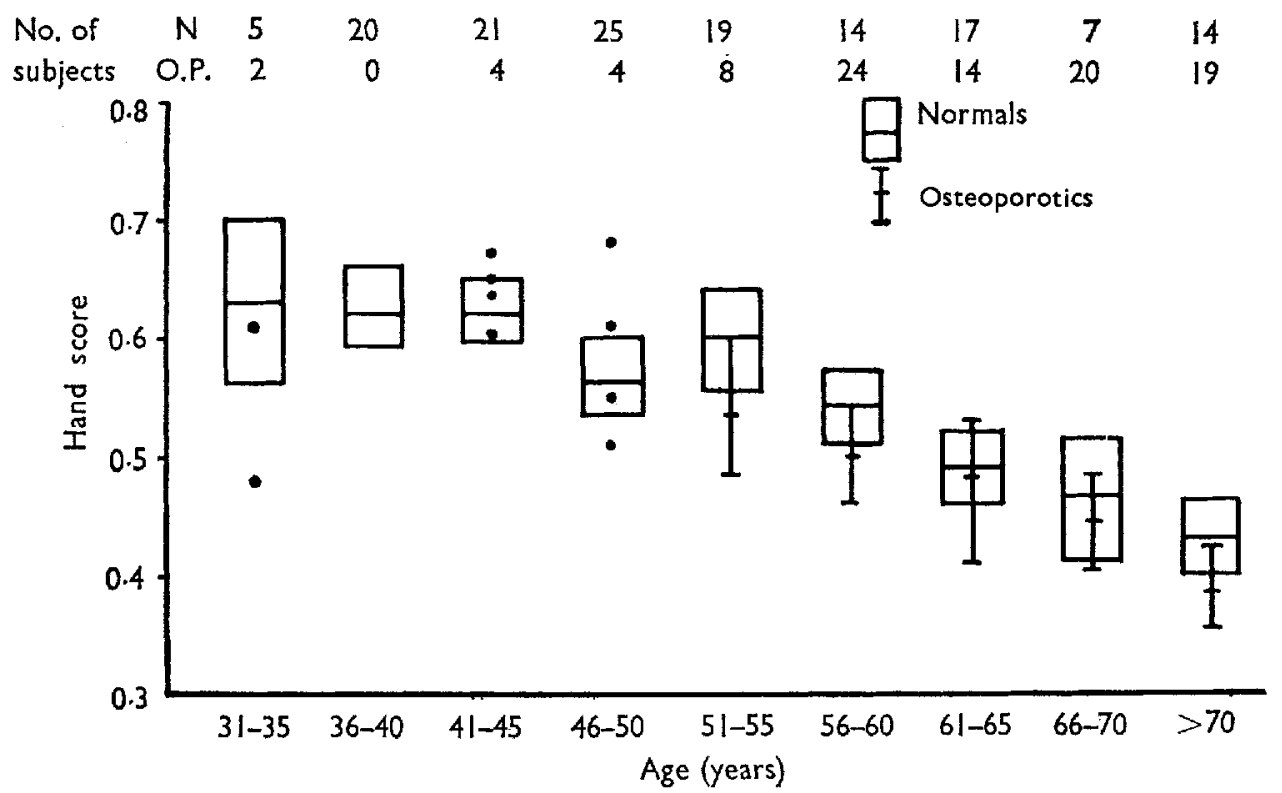

Fig. I. Hand score plotted against age in normal and osteoporotic subjects. The mean and 2 SE range in 5 -year age groups is shown.
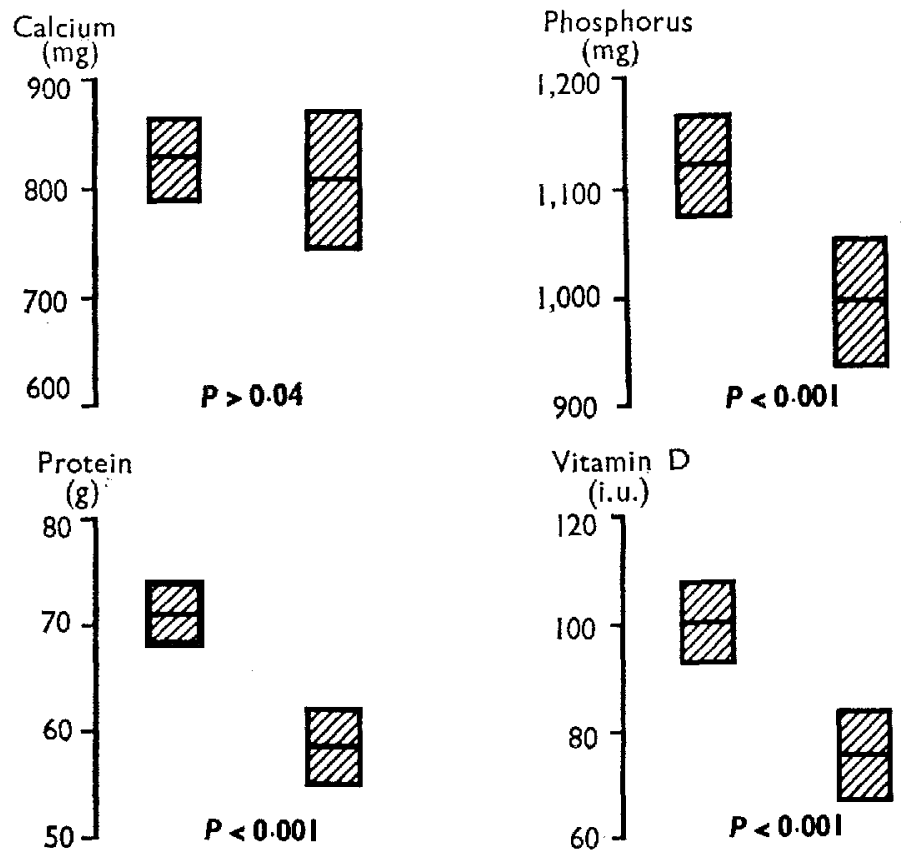

Fig. 2. Dietary intake of calcium, phosphorus, protein and vitamin D in normal and osteoporotic subjects. The mean and 2 SE range is shown. The osteoporotic group has a significantly lower intake of phosphorus, protein and vitamin D. 
$(P<0.001)$, protein $(P<0.001)$, and vitamin D $(P<0.001)$ in the patient group, but the intake of calcium was not significantly different in the two groups. As bodyweight might be expected to influence dietary intakes, the weights of the two groups were compared. The mean weight of the normal women was $62 \cdot 0 \mathrm{~kg}$ ( $\mathrm{SE}=$ $0.93)$, and of the osteoporotic women, $58 \cdot 0 \mathrm{~kg}(\mathrm{SE}=\mathrm{I} \cdot \mathrm{IO})$. The 'osteoporotic' patients were, therefore, slightly but significantly lighter than the normal subjects.

The age distributions of the normal and osteoporotic subjects were compared. As might be expected, the 'osteoporotic' group was found to be significantly older than the control group, (the average age of the osteoporotic patients being $6 r \cdot 8$ years, and of the normal subjects, $5 \mathrm{I} \cdot 6$ years). The body-weights were regressed against age in both groups separately and together, but no significant fall in body-weight with age was found. Since the patient group is both older and lighter than the normal group, the dietary intakes were adjusted to take this into account and the results are shown in Fig. 3. As can be seen, there is no significant difference between the groups when studied in this way.

Calcium

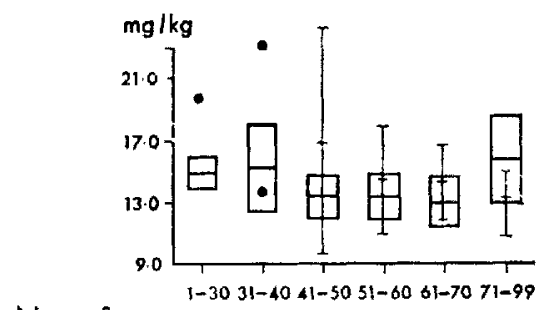

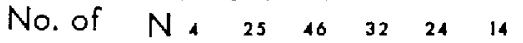
subjects O.P.1 $\quad 2 \quad 8 \quad 32 \quad 34 \quad 19$

Protein

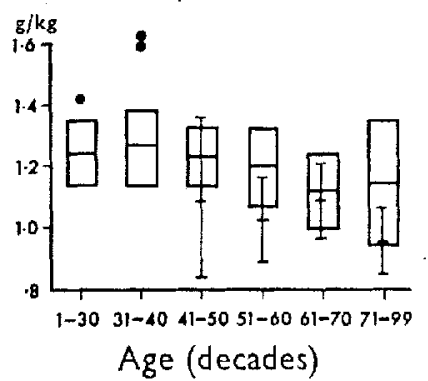

Phosphorus

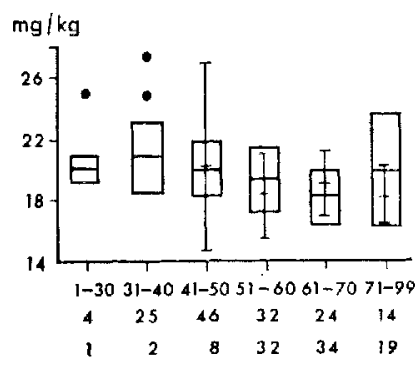

Vitamin D

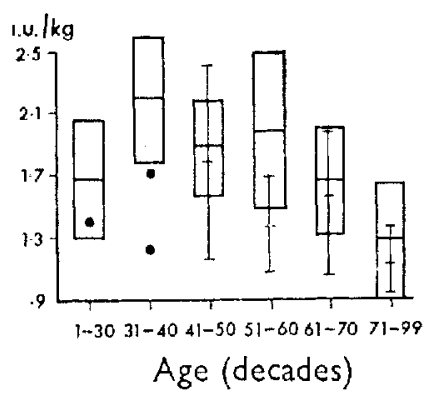

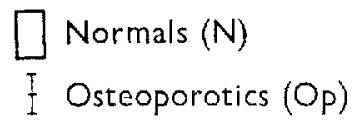

Differences between graphs not significant unless specified at foot of column.

Fig. 3. Dietary intake in the normal and osteoporotic subjects divided by body-weight and plotted against age in ro-year age groups. The mean and $2 \mathrm{SE}$ range is shown. No significant difference between the groups is found.

In both groups, the dietary intakes appeared to fall with age and this was further investigated. The results are shown in Table 3. The dietary intakes are correlated with age in both groups separately and combined. The analysis was repeated after 27 (2) 7 
Table 3. Correlation analysis of dietary constituents and dietary constituents/kg body-weight $(y)$ on age $(x)$

\begin{tabular}{|c|c|c|c|c|c|}
\hline \multirow[b]{2}{*}{ Subjects } & \multirow[b]{2}{*}{$\begin{array}{l}\text { Dietary } \\
\text { constituent }\end{array}$} & \multicolumn{2}{|c|}{ Daily intake } & \multicolumn{2}{|c|}{ Daily intake/kg body-weight } \\
\hline & & $\begin{array}{l}\text { Correlation } \\
\text { coefficient }(r)\end{array}$ & $P$ & $\begin{array}{l}\text { Correlation } \\
\text { coefficient }(r)\end{array}$ & $P$ \\
\hline Normals & $\begin{array}{l}\text { Calcium } \\
\text { Phosphorus } \\
\text { Protein } \\
\text { Vitamin D }\end{array}$ & $\begin{array}{rl} & \text { Not si } \\
-0.2 & -0.2 \\
-0.2 & 0.18\end{array}$ & $\begin{array}{l}\text { lant } \\
<0.02 \\
<0.005 \\
<0.05\end{array}$ & \multicolumn{2}{|c|}{$\begin{array}{l}\text { Not significant } \\
\text { Not significant } \\
\text { Not significant }\end{array}$} \\
\hline 'Osteoporotics' & $\begin{array}{l}\text { Calcium } \\
\text { Phosphorus } \\
\text { Protein } \\
\text { Vitamin D }\end{array}$ & \multicolumn{2}{|c|}{$\begin{array}{l}\text { Not significant } \\
\text { Not significant }\end{array}$} & \multicolumn{2}{|c|}{$\begin{array}{l}\text { Not significant } \\
\text { Not significant } \\
\text { Not significant } \\
\text { Not significant }\end{array}$} \\
\hline $\begin{array}{l}\text { Normals and } \\
\text { 'osteoporotics' }\end{array}$ & $\begin{array}{l}\text { Calcium } \\
\text { Phosphorus } \\
\text { Protein } \\
\text { Vitamin D }\end{array}$ & $\begin{array}{l}-0.14 \\
-0.26 \\
-0.36 \\
-0.22\end{array}$ & $\begin{array}{l}<0.05 \\
<0.001 \\
<0.001 \\
<0.001\end{array}$ & $\begin{array}{l}\quad \text { Nots } \\
-0.14 \\
-0.22 \\
-0.21\end{array}$ & $\begin{array}{l}\text { ant } \\
<0.05 \\
<0.001 \\
<0.001\end{array}$ \\
\hline
\end{tabular}

the dietary intakes were divided by body-weight. The intakes of phosphorus, protein and vitamin $\mathrm{D}$, but not the intake of calcium, fell significantly with age in the normal subjects. However, when the dietary intake was divided by body-weight no significant relation between intake and age was found. In the patient group, only the protein intake, not divided by body-weight, showed any significant fall with age. When the groups were combined, all dietary intakes showed a small fall with age. When the intakes were divided by body-weight, there was a fall in the intake of phosphorus, protein and vitamin D but not of calcium.

The absorption of calcium as measured by the radioactive calcium absorption test is plotted against age in ro-year age groups, and the results are shown in Fig. 4. There is no significant difference between the groups except between $6 \mathbf{I}-70$ years. There was no significant fall with age when the groups were studied separately, but when both were taken together there was a small but significant fall in absorption with age $(r=0.18: P<0.05)$. Since body-weight would be expected to influence the measurement of the plasma level at $\mathbf{2} \mathrm{h}$ after ingestion of the radioisotope because the calcium pool would be larger in the heavier subject, the $2 \mathrm{~h}$ serum value was divided by bodyweight. No significant difference emerged between the groups, and no significant change in absorption occurred with age in either group separately or taken together.

The urinary excretion of calcium as measured by the mean of two separate estimations of the calcium:creatinine ratio in the two groups did not differ significantly (Fig. 5). Again, when regressed against age, there was no correlation with age when the groups were compared separately or together.

\section{Discussion}

The striking feature in this study is the similarity between two groups of subjects selected in two completely different ways. The normal subjects were selected as described before (Nordin et al. I966) by approaching relatives and friends visiting patients in the general medical wards in the Western Infirmary. The patient group 


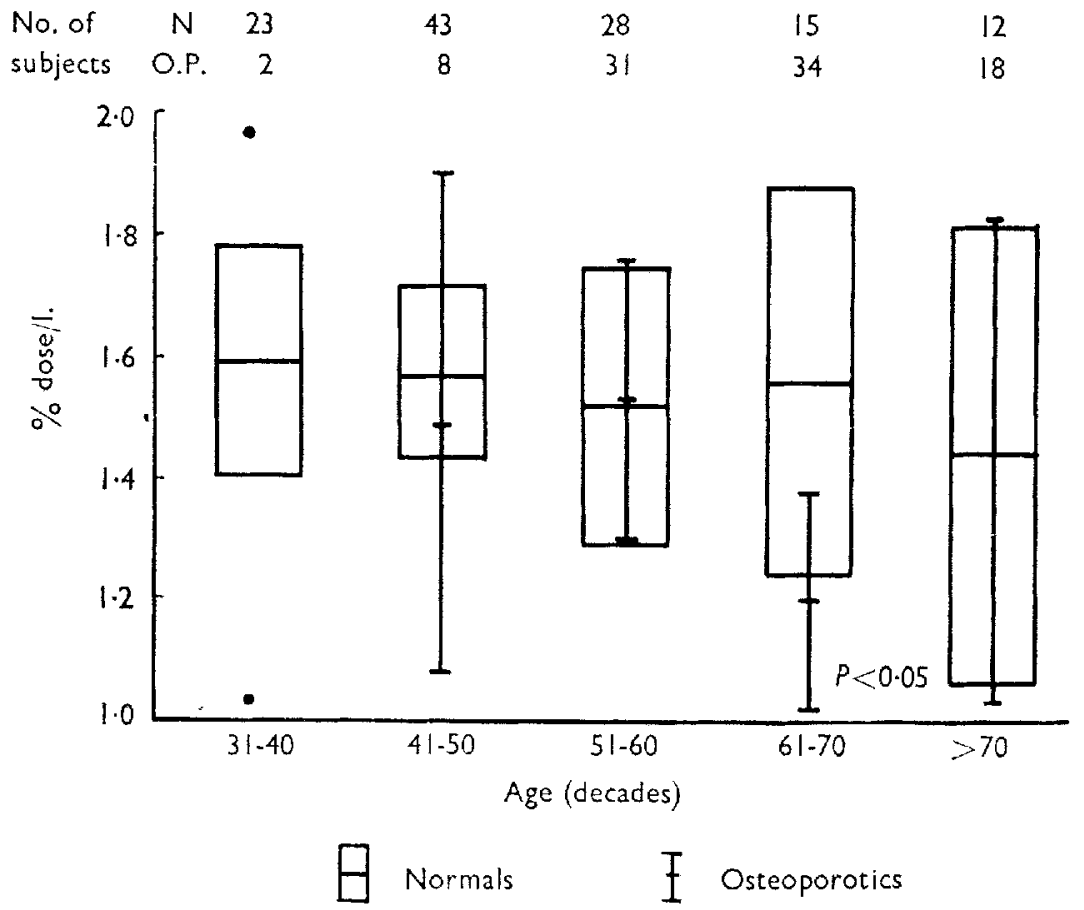

Fig. 4. Calcium absorption measured with ${ }^{45} \mathrm{Ca}$ in the normal and osteoporotic subjects. The mean and 2 SE range in ro-year age groups is plotted against age. The groups do not differ significantly, except in the group $6 \mathrm{I}-70$ years.

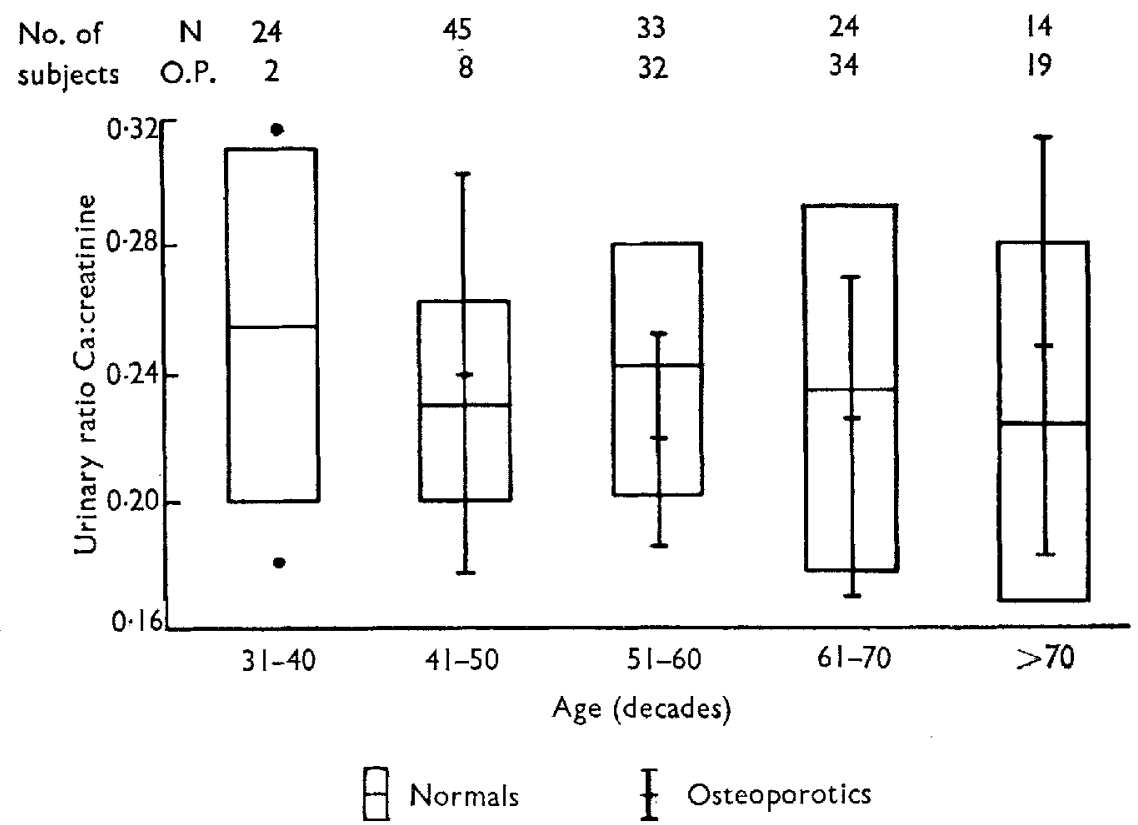

Fig. 5. The mean and 2 SE range of two estimations of the urinary calcium: creatinine ratio plotted against age in Io-year age groups in the normal and osteoporotic subjects. No significant difference between the groups is seen. 
consisted of patients who had been referred to a special clinic because they were thought to be osteoporotic. All had presented with symptoms such as backache or had had a recent fracture, and the referring physician or surgeon had felt that the patient had osteoporosis after the X-rays had been inspected. All the patients had serum calcium and phosphorus measured, and a calcium:creatinine ratio and phosphate excretion were estimated by measuring the phosphate excretion index (Nordin $\&$ Fraser, 1960). In this way, patients who had evidence of other bone disease were excluded. The patient group constituted an older and lighter population, and a higher proportion had had an artificial menopause, but the groups were otherwise similar. The age of onset of the menopause in the two groups did not differ significantly. The distribution within the social classes of the two groups was similar, both showing a higher proportion of patients in social class 3 (skilled workers) which almost certainly reflects the population served by the hospital. The dietary intakes of the two groups showed a significantly lower intake of phosphorus, protein and vitamin $\mathrm{D}$, but not of calcium in the patient group, but once age and weight were allowed for, these differences disappeared. The groups were very similar in their absorption of calcium as measured by an isotope test of absorption using ${ }^{45} \mathrm{Ca}$, and no difference was found in the urinary output of calcium as measured by the mean of calcium: creatinine ratios in the urine.

Though the patient group had significantly lower X-ray indices and densities than the normal group, they were older, and it is now clearly established that X-ray indices fall with age (Meema \& Meema, I963; Nordin et al. 1966; Fujita, Orimo \& Yoshikawa, 1966; Morgan, Spiers, Pulvertaft \& Fourman, 1967; Smith, Anderson, Shimmins \& Speirs, 1968 ). Once age was allowed for, there was a striking similarity between the groups in the measurements of bone mass. Both groups also showed a highly significant fall with age.

Osteoporosis is said to exist when the amount of bone tissue per unit volume is decreased, the remaining bone being normal. In view of the striking similarity between these two groups, however, it is evident that this definition lacks precision. Granted that osteoporosis is a condition in which the amount of bone is diminished, then it must be referred to a normal standard below which the condition is pathological. This problem was further considered by Smith, Anderson, Shimmins, Speirs \& Barnett (1968). The X-ray measurement used in that study was a measure obtained from a densitometric method applied to the third metacarpal of the right hand (Anderson, Shimmins \& Smith, I 966 ). This showed that patients who had a normal amount of bone for their age still had a significant degree of spinal biconcavity and crush fractures. Further, it was found that a significant degree of biconcavity occurred when the amount of bone fell below the $95 \%$ confidence limits for the population between the ages of 30 and $4^{\circ}$ years when the amount of bone mineral was at its peak. Newton-John \& Morgan (I968) showed similarly that the rise in the incidence of fracture of the wrist and neck of the femur was directly related to the fall in bone mass. This means that with increasing age, a higher and higher proportion of the population is at risk and, as Smith, Anderson, Shimmins, Speirs \& 
Barnett (I968) have shown, this risk rises sharply once the amount of bone falls below a certain critical value.

In the present study, there was a slight fall in calcium intake with age. There was a more significant fall in the intake of phosphorus, protein and vitamin $D$ with age. There was a very significant fall in bone mass with age. Though these dietary changes with age are small, in fact only a small negative balance of less than $30 \mathrm{mg}$ calcium/day would be enough to account for the loss of bone in these subjects. However, this does not necessarily mean that dietary intake is related to the development of osteoporosis, as both the fall in X-ray measurement and X-ray score could be a function of ageing.

\section{Summary}

Two groups of subjects were studied. One was a group of normal subjects and the other a group of patients referred to a special clinic because they were thought to be osteoporotic.

The two groups were strikingly similar once age and weight differences were allowed for. Their X-ray measurements did not differ significantly. There was no difference between the groups in relation to dietary intake of calcium, phosphorus, protein and vitamin D. Calcium absorption and urinary excretion were similar in both groups. The X-ray indices fell with age in both groups. A fall was noted in the dietary intake of phosphorus, protein and vitamin $\mathrm{D}$ with age. There was a smaller fall in calcium intake with age. There was a small fall in the absorption of calcium with age, but no change in urinary calcium.

\section{REFERENCES}

Albright, F., Burnett, O. H., Cope, O. \& Parsons, W. (194I). F. clin. Endocr. Metab. I, 7 11.

Albright, F., Smith, P. H. \& Richardson, A. M. (194I). F. Am. med. Ass. х16, 2465.

Anderson, I. A. (1950). Q. $7 l$ Med. 19, 67.

Anderson, J. B., Shimmins, J. \& Smith, D. A. (1966). Br. F. Radiol. 39, 443.

Beck, J. \& Nordin, B. E. C. (ro60). F. path. Bact. 80, 39 r.

Bhandarkar, S. D., Bluhm, M., MacGregor, J. \& Nordin, B. E. C. (т961). Br, med. F. ii, 139.

Collins, D. H. (1959). In Modern Trends In Diseases of The Vertebral Coltemn, p. IOI. [R. Nassim and H. Jackson, editors.J London: Butterworth \& Co.

Fujita, T., Orimo, H. \& Yoshikawa, M. (1966). I. Am. Geriat. Soc. I4, 350.

Greaves, J. P., Scott, M. G. \& Scott, P. P. (1959). F. Physiol., Lond. 146, 36P.

Harrison, M. \& Fraser, R. (r960). $\mathscr{F}$. Endocr. 21, 197 .

Harrison, M. \& Fraser, R. (196I). Lancet i, IOI 5.

Jowsey, J. \& Gershon-Cohen, J. (I964). In Bone and Tooth. [H. J. J. Blackwood, editor.] London: Pergamon Press.

Light, R. F. \& Frey, C. N. (194I). Proc. Soc. exp. Biol. Med. 48, $25^{6 .}$

Meema, H. E. \& Meema, S. $\left(1_{96}\right)$. F. Am. Geriat. Soc. I1, г1 70.

Morgan, D. B., Spiers, F. W., Pulvertaft, C. N. \& Fourman, P. (1967). F. clin. Radiol. r8, 101.

Newton-John, H. F. \& Morgan, D. B. (I968), Lancet i, 232.

Nordin, B. E. C. (1958). Br. med. F. i, I4I5.

Nordin, B. E. C. (I960). In Bone as a Tissue, p. 46. [K. Rodahl, editor.] New York: McGraw-Hill Book Co. Ine.

Nordin, B. E. C. (196г). Lancet i, гог I.

Nordin, B. E. C. (1962). Am. F. clin. Nutr. 1o, 384 .

Nordin, B. E. C. \& Fraser, R. (1960). Lancet i, 947 .

Nordin, B. E. C., MacGregor, J. \& Smith, D. A. (I966). Q. Fl Med. 35, 25. 
Owen, E. C., Irving, J. I. \& Lyall, A. (1940). Acta med. scand. 103, 235.

Smith, D. A., Anderson, J. B., Shimmins, J. \& Speirs, C. F. (1968). F. clin. Radiol. (In the Press.)

Smith, D. A., Anderson, J. B., Shimmins, J., Speirs, C. F. \& Barnett, E. (1968). Proceedings of a Symposium on Progress in Methods of Bone Mineral Measurement, Washington, DC, February 1968. [G. D. Whedon and J. R. Cameron, editors.] In Clin. Orthop. (In the Press.)

Smith, R. W. \& Frame, B. (1965). New Engl. Y. Med. 273, 73.

Whedon, G. D. (1959). Fedn Proc. Fedn Am. Socs exp. Biol. I8, ir12. 